\title{
Identification and prioritization the factors affecting the insurance industry customer preferences using KANO and AHP model (case study:the city of Kashan)
}

\author{
Ali Sabbaghian ${ }^{1}$, Maryam Edalaty ${ }^{2 *}$ \\ 1- Assistant Professor of Islamic Azad University of Naragh \\ 2- Master of Business Management, Islamic Azad University of Naragh medalati2003@yahoo.com
}

\section{Abstract}

It is noticed that the environmental changes in world market, impress the insurance companies, accepting new models for their business, as it is important to utilize the customers ideas for services, especially that the customers are affected by the environmental changes. The satisfied customers act for developing the insurance culture as, applying effective strategy, increasing the customer services and attracting the customers. In modern variable environment, it is necessary that the companies adopt themselves with variations, for continuing to survive life. Creating an appropriate structure is one of the main components and integrated features of today's societies and in the present competitive world, successful companies are those that of a step above theirs competitors. In this paper, it is tried to identificate the effective indicators in customer preferences using KANO model and finally prioritized using AHP model.

Keywords: sample, $K A N O, A H P$, insuranced preferences 


\section{1- Introduction}

Novedays, the customers have very critical role in the economic and international interactions. Customer relating management has been proposed as a long-term relationship with the customers, so that the made changes have helped to its performance method.(light, 2001)

The customer relating management is a business strategy and its implementation will attract and maintain and enhance the customers.

Aware of the quality of service concept and efforting to improve its service quality can increase the customer satisfaction.

Nowedays, through the use of information and communication technologies, organizations can offer lower prices different products and services to customers at the same time (Peppard, 2003).

The insurance companies are one of a dynamic and important institutions in many countries. These companies are important with respect to the features and benefits to the community, and insurance bye transfering the risk from the general population to itself, make the cause of peace and social welfare. Insurance companies, catching insurace premiums from the people, invest them in investing or exchange companies and grow their countries. These companies,in order to provide appropriate services to insured peoples, should have a closely relationship with buyers, especially buyers of non-compulsory insurances to aware of their needs and offer them suitable insurance.

In this paper, a real framework is studied for the prioritization and selection of the most important factors for insured prefering in Kashan through a combination of KANO and AHP model.

\section{2- Research Method}

The research method is the collection of rules, tools and reliable and systematic ways to review the facts, explore the unknown and achieve solutions to problems.

Identification method is the base of every science and validation of every science is based on the identification method that is used.

This article base of goals that will follow, is applied because the results of customer preference in the field of insurance companies can be exploited in the insurance industry and the other insurance companies.

\section{2-1- Statistics society}

For research purposes, we should define the society that the sample is chosen from. This definition must be so clear that there aren't any questions about the generalizability or the application of the results of each member of society.

The statistics society is the number of desired elements in that of one specific character. Specific character is the character that is shared between all elements of the statistics society, and distinctive the statistics society from other communities. "Sarmad and others, 2007" Research Methodology in Behavioral Sciences "10 edition, Tehran, Agah Publishers.

The Statistics society of the this study are managers and assistant managers of the insurance industry of Kashan City.

Since access to customers and for completing the questionnaire is difficult, the questionnaires was Distribute between the managers and assistant managers of insurance industry, that are members of insured.

\section{2-2- statistics sample.}

Decision about the sample volume, is very important in terms of the accuracy of the results of sampling and saving time and money.

It is clear that the small size causes inaccuracy of results, and a large sample size would be too time consuming and expensive.

As a result, the most suitable size may be selected in term of time, accuracy and cost. 
Considering the above. to determine the sample according the advisor professor, the questionnaire was distributed between 25 managers that the number of questionnaires returned was 20 .

\section{2-3- Data analysis method}

Data analysis is a multi-stage process in which the data collected through the use of the sample are summarized, coded, classified and then processed to answer research questions and hypotheses. In this process, the data are refined in terms of conceptual and experimental and finally, the various techniques of statistical have an important role in inference and generalizations. (Khaki, 1997)

\section{2-3-1- Variable descriptions}

In this section, the general profile of experts, such as education, work experience, and the organization post is stated. It should be noted that in this study, experts and insurance experts of Kashan city that are being employed in Iran, Parsian, Dana, Alborz, Asia, Razi and Karafarin insurance, are asked to answer a questionnaire research.

Education: data is as follows:

Table 1: variable abundance of education

\begin{tabular}{|c|c|c|c|c|}
\hline Education & abundance & Relative abundance & The cumulative abundance & Condensation percent \\
\hline undergraduate education & 12 & 0.6 & 12 & 6 \\
\hline graduate education & 6 & 0.3 & 18 & 0.9 \\
\hline Ph.D education & 2 & 0.1 & 20 & 1 \\
\hline Sum & 20 & 1 & & \\
\hline
\end{tabular}

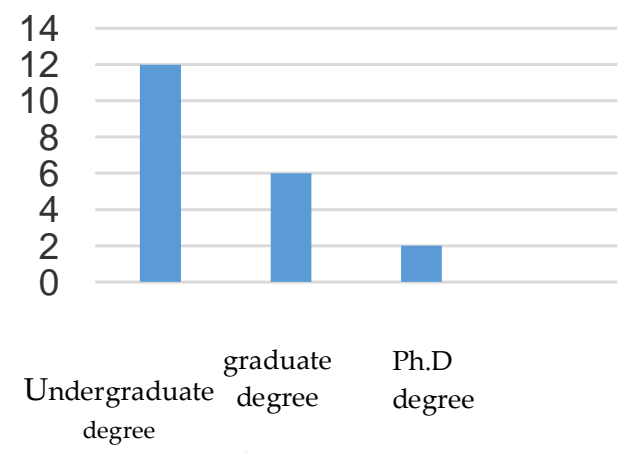

Figure 1: Diagram of education variable abundance

The above table shows the status of education variable among the respondent. According to the results of above table, $60 \%$ of respondents have undergraduate education, $30 \%$ of respondents have graduate education and $10 \%$ of respondents have Ph.D education.

\section{The organization post:}

Table 2: organizational status abundance table

\begin{tabular}{|c|c|c|c|c|}
\hline organization post & abundance & Relative abundance & The cumulative abundance & Condensation percent \\
\hline managers & 6 & 0.3 & 6 & 0.3 \\
\hline assistant & 14 & 0.7 & 20 & 1 \\
\hline sum & 20 & 1 & & \\
\hline
\end{tabular}

The above table shows the organizational status of the respondents.
The following chart shows the abundance of respondents according to organizational post variables. 


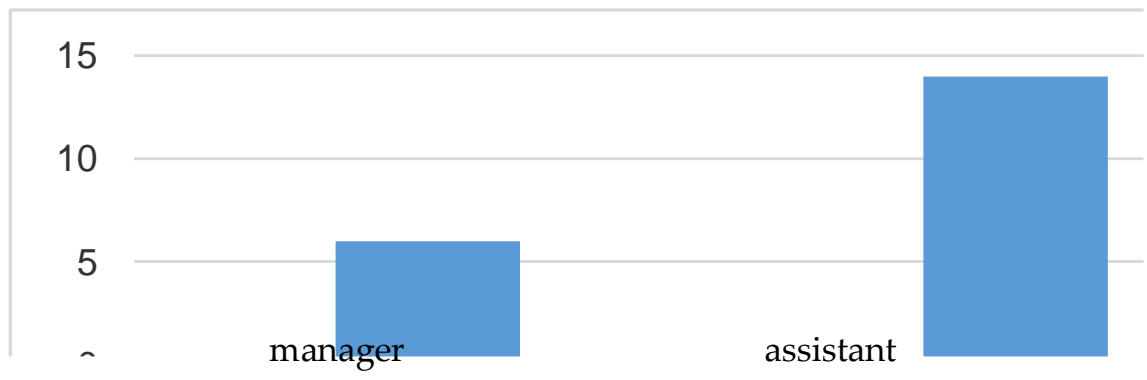

Figure 2: Diagram of respondents organizational status variable abundance

\section{Service history:}

Table 3: Service history variable abundance table

\begin{tabular}{|c|c|c|c|c|}
\hline Service history & abundance & relative abundance & cumulative abundance & Condensation percen \\
\hline 3 to 6 years & 4 & 0.2 & 4 & 0.2 \\
\hline 6 to 10 years & 3 & 0.15 & 7 & 0.35 \\
\hline 10 to 15 years & 8 & 0.4 & 15 & 0.75 \\
\hline 15 to 25 years & 5 & 0.25 & 20 & 1 \\
\hline
\end{tabular}

The above table shows the service history variable status between the respondents.

According to the results of table, $25 \%$ of The following chart shows the respondents are between 15 and 25 years of history variable. experience in the insurance industry.

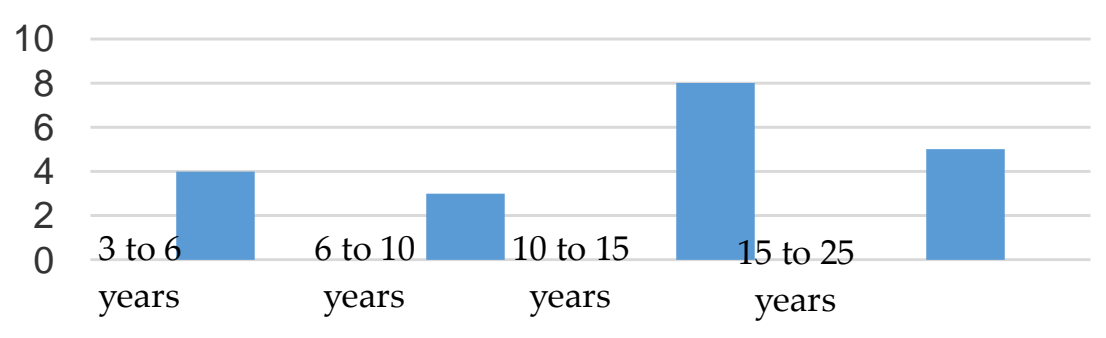

Figure 3: Diagram of the service history variable abundance

\section{3- Conclusion}

In this study, the factors affecting the insuranced preferences are classified in three main groups of basic needs, performance and motivation (based on Kano model). In order to prioritize the effective factors in insurance preferences, the main factors and their subsidiaries using the Expert Choice software and managers, experts and employees of the insurance industry ideas were ranked as follows.

the main factors of insuranced preferences are as follows.

Table 7: the main factors

\begin{tabular}{|c|c|}
\hline The main factors & Weight \\
\hline basic & 0.551 \\
\hline performance & 0.324 \\
\hline motivational & 0.125 \\
\hline
\end{tabular}


Table 8: the basic requirement

\begin{tabular}{|c|c|c|}
\hline \multicolumn{2}{|c|}{ the basic requirement } \\
\hline Row & Indicators & Weight \\
\hline 1 & providing clear contracts & $0.551^{*} 0.187=0.103$ \\
\hline 2 & the proportionality of compensation and insurance premium & $0.551^{*} 0.212=0.116$ \\
\hline 3 & ease of operation & $0.551^{*} 0.089=0.049$ \\
\hline 4 & protection of customer data and customer goodwill to employees & $0.551^{*} 0.159=0.087$ \\
\hline 5 & good and strong communication with customer & $0.551^{*} 0.136=0.074$ \\
\hline 6 & adherence to the commitments undertaken by insurance & $0.551^{*} 0.217=0.119$ \\
\hline
\end{tabular}

Table 9: the performance requirement

\begin{tabular}{|c|c|c|}
\hline \multicolumn{3}{|c|}{ the performance requirement } \\
\hline Row & Indicators & Weight \\
\hline 1 & The distribution of insurance offices in the city and availability in place & $0.324^{*} 0.197=0.063$ \\
\hline 2 & compared with other insurances provide differentiated services & $0.324^{*} 0.216=0.069$ \\
\hline 3 & proper understanding of customers needs and appropriate mechanisms to assist. & $0.324^{*} 0.102=0.033$ \\
\hline 4 & modern office and equipments & $0.324^{*} 0.088=0.028$ \\
\hline 5 & awarding incentive packages to customers as well as having facilities such as parking, & $0.324^{*} 0.120=0.038$ \\
\hline 6 & feeception and ... & $0.324^{*} 0.091=0.029$ \\
\hline 7 & Having mobile unit to provide insurance services & $0.324^{*} 0.061=0.019$ \\
\hline 8 & Taking of modern technology to provide services (such as sending SMS, e-mail and & $0.324^{*} 0.124=0.040$ \\
\end{tabular}

Table 10: the motivational requirement

\begin{tabular}{|c|c|c|}
\hline \multicolumn{2}{|c|}{ the motivational requirement } & Weight \\
\hline Row & Indicators & $0.324^{*} 0.197=0.063$ \\
\hline 1 & $\begin{array}{c}\text { ensuring the provision of services in the form of commitment and investigate customer } \\
\text { complaints }\end{array}$ & $0.324^{*} 0.216=0.069$ \\
\hline 2 & having good experience in identifying and finding and solving customer problems & $0.324^{*} 0.102=0.033$ \\
\hline 3 & adequate knowledge to solve customer problems & $0.324^{*} 0.088=0.028$ \\
\hline 4 & working at the first visit and avoiding unnecessary repeat visits & $0.324^{*} 0.120=0.038$ \\
\hline 5 & declaration of work process steps as appropriate to the client & $0.324^{*} 0.091=0.029$ \\
\hline 6 & The time of services (week days and hours), and compatibility of branch working time & $0.324^{*} 0.061=0.019$ \\
\hline 7 & the ability of quick response to customers & $0.324^{*} 0.124=0.040$ \\
\hline 8 &
\end{tabular}

\section{4- Suggestion}

For future research, it is suggested to study previous research and extraction of affecting factors in customer preferences for prioritize and provide suggestions to the organizations and companies.

\section{Refrences}

A conceptual model of service quality and its implication for future research :journal of marketing, vol49, pp 41-50.
A conceptual model of service quality and its implication for future research: journal of marketing, vol49, pp 41-50.

Affiaine Ahmad, Zalina Sungip, (2008),An Assessment on Service Quality in Malaysia Insurance Industry, Communications of the IBIMA.vol 1,13-26.

Bahman Karegar Shahamat, Bahman Sharif, Majid Ghanbarnjad Esfaghanasary, (2011), Recognition and Ranking the Effective Factor on Customer Satisfaction Through Kano Model and AHP. 
Bonacorsi, steven 2008.' Kano model and critical to quality tree. resources- home.web

Harvey, D. (2002) "customers-theHidden Treat to your business" capstone, Oxford.

Jay, R. (2001) "winning minds-the ultimate book of business leadership" Capstone.

Richard L. Oliver (1981),"Developing Better Measures of Consumer Satisfaction: Some Preliminary Results", in NA - Advances in Consumer Research Volume 08, eds. Kent B. Monroe, Ann Abor, MI: Association.

Mansouri Jajaee Sharareh, Fauziah Binti Sheikh Ahmad,(2012), Evaluating the Relationship between Service Quality and Customer Satisfaction in the Australian Car Industry 